\title{
Think twice before using narrow buffers: Attenuating mowing-induced arthropod spillover at forest - grassland edges
}

\author{
Csaba Tölgyesi ${ }^{\mathrm{a}, \mathrm{b}, *}$, Péter Császár ${ }^{\mathrm{a}}$, Attila Torma ${ }^{\mathrm{a}}$, Péter Török ${ }^{\mathrm{b}}$, Zoltán Bátori ${ }^{\mathrm{a}}$, Róbert Gallé ${ }^{\mathrm{a}}$ \\ a Department of Ecology, University of Szeged, Közép fasor 52, H-6726 Szeged, Hungary \\ ${ }^{\mathrm{b}}$ MTA-DE Lendület Functional and Restoration Ecology Research Group, Egyetem tér 1, H-4032 Debrecen, Hungary
}

\section{A R T I C L E I N F O}

\section{Keywords:}

Carabid beetle

Forest edge

Grassland management

Mowing

Spider

Spillover

\begin{abstract}
A B S T R A C T
Spillover between agricultural land and natural habitats is recognised as an important mechanism shaping biodiversity and ecosystem functions. Its spatio-temporal patterns and magnitude are thoroughly described in the literature and it is often stated that spillover should be considered in conservation planning. In fact studies that implement and test active interventions to modulate spillover are scarce. Therefore, we studied the spillover of spiders and carabids between hay meadows and natural forests after mowing and tested whether leaving unmown buffer strips in the edges can mitigate undesirable aspects of mowing-induced spillover. We found that mowing affected the assemblages both in the meadows and forests and, interestingly, changes were more profound in the forests. Mowing reduced the spillover of forest assemblages into meadows. Mowing also led to the retraction of forest assemblages from the peripheral zones of forests but did not trigger an influx of meadow assemblages into the forests. Wide $(10 \mathrm{~m})$ unmown buffers attenuated or completely offset most of these effects. Leaving narrow $(5 \mathrm{~m}$ ) buffers had unexpected consequences, as they did not function only as buffers but as facilitators of forest-ward spillover from meadows, potentially compromising ecological interactions such as predation or competition in forests. We conclude that using wide buffers can be recommended as a refinement of standard management practices in hay meadow-forest mosaics. Narrow buffers should be applied with great caution and should generally be avoided if the forest-specific assemblages are of conservation interest.
\end{abstract}

\section{Introduction}

Semi-natural grasslands are decreasing in area and naturalness across Europe due to management intensification, abandonment and transformation to other land use types (Báldi et al., 2013; Dengler et al., 2014). Best management practices for the preservation of remaining grasslands include extensive grazing with various livestock and/or mowing once or a few times a year (Tälle et al., 2016; Török et al., 2016). Extensive grazing with appropriate livestock may mimic prehistorical disturbance regimes of wild megaherbivores (Vera, 2002; Sutherland, 2002) and can create heterogeneous vegetation (Marty, 2005; Tölgyesi et al., 2015), which supports high arthropod diversity (Lambert et al., 2007; Woodcock et al., 2006). Conversely, mowing, which is nowadays performed by high-power machines, leads to more homogenous habitat structure and arthropod assemblages (Cizek et al., 2012). Mowing machines also mechanically kill a large number of animals from insects (Thorbek and Bilde, 2004) to birds (Vadász and Lóránt, 2015). The physical environmental conditions on freshly mown meadows may be beyond the limit of tolerance of the survivors and they are also more visible to predators (Opatovsky and Lubin, 2012). To counteract the negative effects of mowing, several recommendations have been proposed in the frame of agri-environmental schemes (AES). These include the careful timing of mowing, increased cut height, the combined application of mowing and grazing, and leaving unmown strips or patches, where animals can find shelter and plants can set seed (Buri et al., 2013; Cizek et al., 2012; Humbert et al., 2012a,b; Lebeau et al., 2015; van Klink et al., 2017).

All recommendations listed above aimed to mitigate the negative effect of mowing on grassland biodiversity. However, processes in one habitat can affect the peripheral zones of adjacent habitats through edge effects (Murcia, 1995). Accordingly, the mowing of grasslands can affect the biota of the neighbouring habitats. These effects should be taken into account, particularly if these habitats are of high conservation value (such as forest fragments) and/or if the grassland and nongrassland patches form a natural mosaic or a fragmented landscape. In such landscapes the edge to patch interior ratio is high, thus the potentially affected proportion of non-grassland habitats is also high (Cook et al., 2002; Madeira et al., 2016).

\footnotetext{
* Corresponding author at: Department of Ecology, University of Szeged, Közép fasor 52, H-6726 Szeged, Hungary.

E-mail addresses: festuca7@yahoo.com (C. Tölgyesi), csaszi124@gmail.com (P. Császár), torma_a@yahoo.com (A. Torma), molinia@gmail.com (P. Török), zbatory@gmail.com (Z. Bátori), galle.robert@gmail.com (R. Gallé).
} 
A frequently studied manifestation of edge effects is the spillover of arthropods, i.e. their periodic/annual movement or foraging across habitat edges (Rand et al., 2006, Tscharntke et al., 2012). Spillover can be traced back to various ecological reasons. Differences in productivity can lead to the movement of organisms from a productive habitat to a less productive neighbouring habitat in a passive, diffusion-like manner, corresponding to the source-sink dynamics described by Dunning et al. (1992). Conversely, an abrupt decline in habitat quality can trigger active emigration from a patch into a neighbouring one (Holt and Hochberg, 2001; Thorbek and Bilde, 2004). Landscape complementation (i.e. the need of an organism for both neighbouring habitats to complete its life-cycle) and landscape supplementation (i.e. if the neighbouring habitats provide alternatives for certain resources) can also explain spillover (Dunning et al., 1992; Fahrig et al., 2011; Tscharntke et al., 2012). Spillover has been detected between various habitat pairs such as adjacent arable fields and natural grasslands (Madeira et al., 2016; Rand and Louda, 2006), natural forests and forest plantations (Lucey and Hill, 2012), grasslands and coniferous forests (Lacasella et al., 2015) and even between fields of different crop types (Duflot et al., 2016; Macfadyen and Muller, 2013), indicating that it is a wide-spread phenomenon. The relevance of spillover for conservation issues is emphasised in most of these studies (e.g. Pryke and Samways, 2012; Schneider et al., 2013), as they claim that the influx of arthropods from the neighbouring habitats can import new ecosystem functions (Blitzer et al., 2012; Rand et al., 2006) but can disrupt some functions by increasing competition or predation (Ries and Sisk, 2004).

In relation to forest-grassland edges it has been found that spillover of forest assemblages into grasslands is more pronounced than spillover of grassland assemblages into forests (Boetzl et al., 2016; Lacasella et al., 2015) as the higher biomass of forests can maintain a higher abundance of arthropods, which then spillover into grasslands according to the source-sink dynamics (Dunning et al., 1992). Mowing, however, causes a rapid deterioration of habitat quality in the grassland, actively driving arthropods out of the affected habitats (Eyre et al., 2013; Opatovsky and Lubin, 2012). Thus, we expect that forest assemblages will show an abrupt decline in their spillover rate into freshly mown grasslands and grassland assemblages will likely be seeking shelter in adjacent forest patches, leading to increased spillover into forests immediately after mowing. Although some seasonal landscape complementation or supplementation can exist between the forests and meadows (Dunning et al., 1992; Fahrig et al., 2011), the effects of modern mowing techniques may cause perturbations in spillover that were unprecedented in earlier times. Thus, there is a need to assess the outlined cross-edge effects of mowing and measures should be taken to offset them if necessary. To date, little effort has been made to address this issue. We therefore designed a field experiment in hay meado$\mathrm{w}$-hardwood grove mosaics in Hungary to study the changes of arthropod assemblages in the peripheral zones of adjacent meadow and forest patches immediately after mowing. We chose spiders and carabid beetles as test organisms because they usually have distinct assemblages in forest and grassland habitats (Noreika and Kotze, 2012), are mobile enough to cross edges, are sensitive to environmental variation at small spatial scales, and occupy an intermediate trophic level, which allocates a key role to them in the maintenance of ecosystem functions (Lacasella et al., 2015; Pearce and Venier, 2006). We focussed only on the peripheral zones of forests and grasslands because spillover is expected to be more pronounced there than farther away from the forest edges (Boetzl et al., 2016). Specifically, we asked the following questions:

(1) Does mowing alter the species composition of spider and carabid assemblages in the peripheral zones of forests and meadows, and can these effects be prevented by leaving unmown buffer strips?

(2) Does mowing cut back on the spillover of forest assemblages, and can it be restored by buffer strips?

(3) Does mowing trigger a quick influx of meadow specific assemblages, and can this be attenuated by buffer strips?

\section{Material and methods}

\subsection{Study area}

We studied a hay meadow-hardwood grove mosaic in the Kiskunság National Park, central Hungary (N46.725 E19.347, $98 \mathrm{~m}$ a.s.1.). The climate is continental with a sub-Mediterranean influence; the annual precipitation is $500-600 \mathrm{~mm}$ and the mean annual temperature is $10-11{ }^{\circ} \mathrm{C}$ (Tölgyesi et al., 2016). Extra water, supplied by groundwater seeping from the adjacent Danube-Tisza Sandy Ridge maintains a vegetation type with high water demand. Hay meadows are characterised by tall grasses, such as Molinia caerulea and Deschampsia caespitosa and form a mosaic with forest patches, characterised by Fraxinus angustifolia subsp. danubialis and Quercus robur. Both forests and meadows provide habitat for several plants (e.g. Gladiolus palustris), invertebrates (e.g. Isophya costata and Phengaris teleius) and birds (e.g. Crex crex and Haliaeetus albicilla) of community interest in the European Union. Both habitats are also listed in the Habitats Directive (European Union 1992). The forest patches are part of a strict forest reserve, in which forestry activities have been banned for 60 years. The meadows are used for extensive hay production and are mown once a year, mostly after mid-July to avoid damage to ground-nesting birds. Some strips or larger blocks (10-15\% of the total area) are left unmown every year for wildlife refuge and to allow the seed production of late summer plants. Meadows are usually mown up to the edges of the forests. In some years in winter, shrubs (e.g. Cornus sanguinea and Frangula alnus) are cut back if they show considerable encroachment towards the meadows. As a result, forest edges are stable in position and have not changed notably since the first military mapping of the region in 1783 (Molnár et al., 1997).

\subsection{Data collection}

In July 2014, we prepared a special mowing plan for the site managers. In four locations, mowing was performed as usual, without leaving any unmown fringe along the forest edges. In other locations, five or ten meters of unmown buffers were left, with four spatial replicates for each width. In four further locations, no mowing was allowed (control). Each of these locations corresponded to an 80-100 m long straight forest edge (Fig. 1A). In each location, we installed eight pitfall traps (128 in total), of which four traps were placed in a line in the peripheral zone of the meadows, approx. $2.5 \mathrm{~m}$ from the forest edges, and four traps parallel to them in the peripheral zone of the forests, approx. $2.5 \mathrm{~m}$ from the forest edge (Fig. 1B). We used 0.51 plastic glasses as traps with an upper diameter of $8 \mathrm{~cm}$. The trapping fluid was ethylene glycol diluted with water $(1 / 2, v / v)$ and a few drops of detergent were also added. The traps were installed immediately after mowing and were open for seven days. We chose this short period because grassland vegetation starts to regenerate from approximately one or two weeks onward, which would have obscured the short-term perturbations of the arthropod assemblages the research was designed to measure.

\subsection{Data processing}

We applied permutational multivariate analysis of variance (perMANOVA) with 1000 permutations to identify the effects of mowing and buffer width on the composition of spider and carabid assemblages. Calculations were performed separately on the untransformed species-abundance matrices of the meadows and forests. Traps were handled separately but their nested arrangement was accounted for in the analysis. If a result was significant, we carried out pair-wise perMANOVAs and adjusted the resulting $P$-values with the FDR method. For a visual representation of compositional patterns, we 


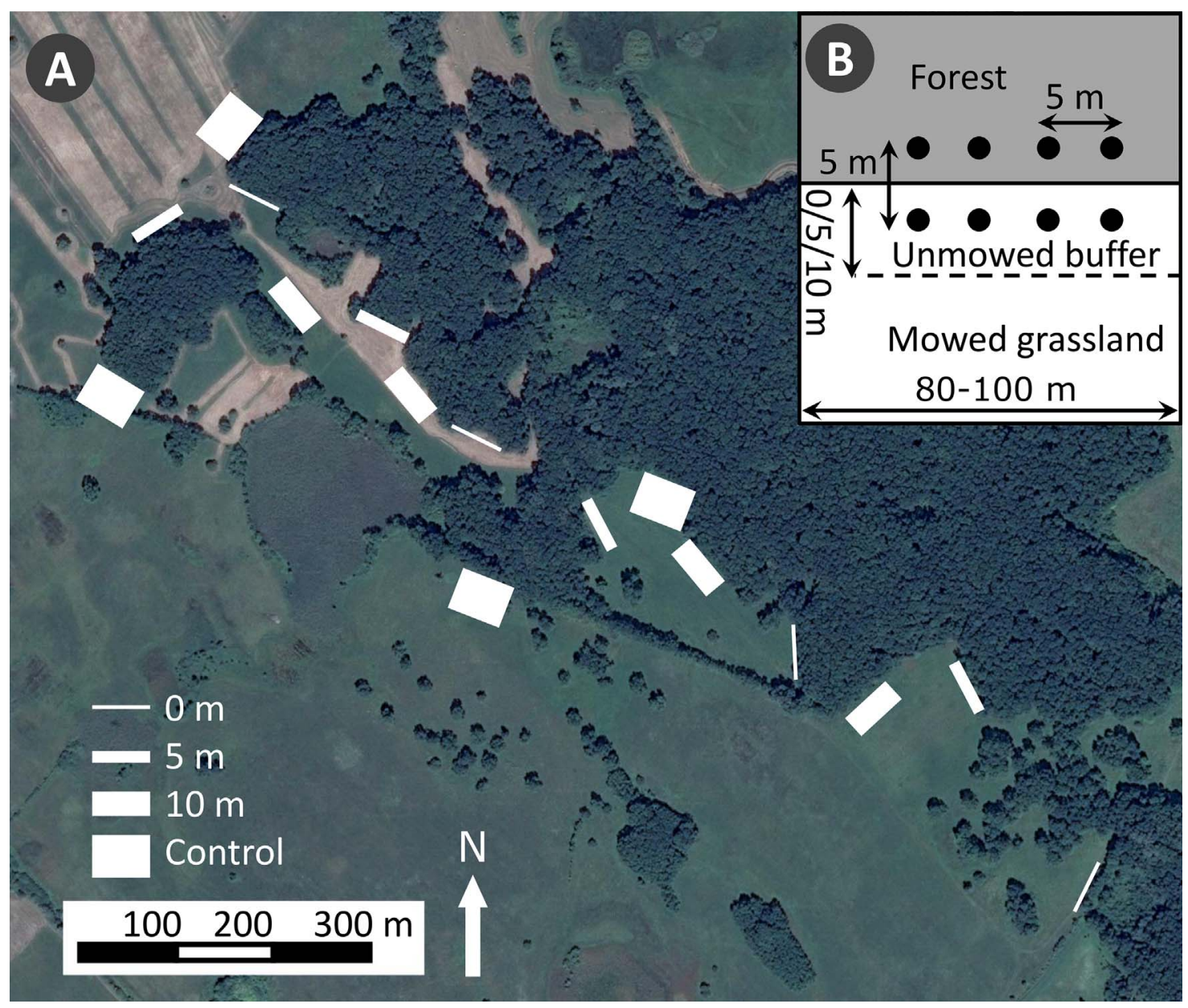

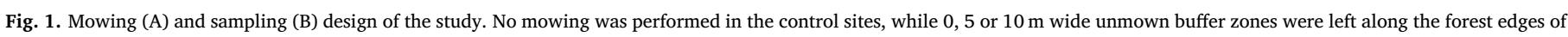

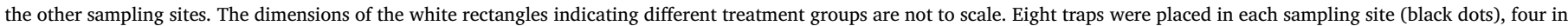
the peripheral zone of the forests and four in that of the meadows.

performed principal component analysis (PCA). Prior to this analysis, the four traps of each location were pooled and the resulting data were square-root transformed.

We prepared generalised linear mixed-effects models (GLMMs) on the untransformed total abundance values of the arthropods using 'treatment type' as the fixed factor (four levels: control and $0 \mathrm{~m}, 5 \mathrm{~m}$ and $10 \mathrm{~m}$ buffer widths) and 'location' as the random factor to account for the spatial non-independence of traps within each location. We used negative binomial error term because the data were overdispersed. Finally, we sorted the species according to their habitat preference into forest specialist, open habitat specialist and generalist species groups following Buchar et al. (2002) for spiders and Freude et al. (2004) and Hurka (1996) for carabids, and prepared similar GLMMs on their abundance. Separate models were made for the meadow and forest data. The significance of the models was assessed by comparing the full model to a null model containing only the random factor. If a model explained a significant proportion of the variability of the data, pairwise comparisons of the factor levels were also considered and the resulting $P$-values were adjusted with the FDR method.

We made all calculations in $R$ environment ( $R$ Core Team, 2014). The perMANOVAs and the PCAs were performed with the 'adonis' and 'rda' functions of the vegan package (Oksanen et al., 2016), respectively. We used the 'glmer.nb' function of the lme4 package (Bates et al., 2015) for the GLMMs. Comparisons of full and respective null models were made with the 'anova' function of the built-in stats package. Pairwise comparisons were assisted by the 'relevel' function and the adjusted $P$ values were calculated with the 'p.adjust' function.

\section{Results}

\subsection{Spiders}

We collected a total of 3035 spiders of 97 species, which included 25 forest specialist, 41 open habitat specialist and 31 generalist species. We caught 1332 individuals in the forests (63 species) and 1703 (79 species) in the meadows. According to the perMANOVAs, the composition of spider assemblages was affected by treatment type, and the effect was significant for both habitats (Table 1). Pairwise comparisons of the forest data revealed that the spider assemblage of the ' $0 \mathrm{~m}$ ' group differed from all other groups. Significant compositional difference was also detected between the ' $5 \mathrm{~m}$ ' and the ' $10 \mathrm{~m}$ ' buffer types. The control did not differ from the ' $5 \mathrm{~m}$ ' and ' $10 \mathrm{~m}$ ' groups. Similarly, the separation of the ' $0 \mathrm{~m}$ ' group was detectable on the PCA scatter plot as well, while the other groups showed a considerable overlap. The separation of the ' $5 \mathrm{~m}$ ' and ' $10 \mathrm{~m}$ ' groups was not clear using the two most important components (Fig. 2A). In the meadows, we found significant differences between the control and all the three treatment groups. Furthermore, the ' $0 \mathrm{~m}$ ' group differed from the ' $5 \mathrm{~m}$ ' and the ' $10 \mathrm{~m}$ ' groups; that is, difference was detected for all group pairs but the ' $5 \mathrm{~m}$ ' and ' $10 \mathrm{~m}$ ' groups. These findings also appear on the PCA scatter plot, with a considerable overlap between groups ' $5 \mathrm{~m}$ ' and ' $10 \mathrm{~m}$ ' and a clearer separation between all other group pairs (Fig. 2B).

The GLMMs of the forest data revealed that treatment significantly affected the total abundance as well as the abundance of forest and open habitat specialist spiders but not that of the generalist ones 
Table 1

perMANOVA results of the spider and carabid assemblages of the peripheral zones of the forests and meadows. 'Total' refers to the full perMANOVAs and the other results are pairwise comparisons. C: control; ${ }^{*} P<.05 ;{ }^{* *} .01<P<.05 ;{ }^{* * *} P<.001 ; P$-values were corrected for multiple comparisons with the FDR method.

\begin{tabular}{|c|c|c|c|c|c|c|c|}
\hline Forest & $F$ & $R^{2}$ & $P$ & Meadow & $F$ & $R^{2}$ & $P$ \\
\hline \multicolumn{8}{|l|}{ SPIDERS } \\
\hline Total & 2.54 & 0.094 & $<.001^{* * *}$ & Total & 3.34 & 0.111 & $<.001^{* * *}$ \\
\hline $\mathrm{C}-0 \mathrm{~m}$ & 2.32 & 0.071 & $.012 *$ & $\mathrm{C}-0 \mathrm{~m}$ & 3.24 & 0.093 & $<.001^{* * *}$ \\
\hline$C-5 m$ & 1.84 & 0.056 & .062 & $C-5 m$ & 2.36 & 0.068 & $.014 *$ \\
\hline $\mathrm{C}-10 \mathrm{~m}$ & 1.21 & 0.039 & .279 & $C-10 m$ & 2.56 & 0.079 & $.005^{* * *}$ \\
\hline $0 m-5 m$ & 2.30 & 0.070 & $.012^{*}$ & $0 m-5 m$ & 2.13 & 0.059 & $.042 *$ \\
\hline $0 m-10 m$ & 2.07 & 0.064 & $.018^{*}$ & $0 m-10 m$ & 3.98 & 0.120 & $.004^{* *}$ \\
\hline $5 m-10 m$ & 2.89 & 0.085 & $.007^{* *}$ & $5 m-10 m$ & 1.25 & 0.039 & .246 \\
\hline \multicolumn{8}{|l|}{ CARABIDS } \\
\hline Total & 2.01 & 0.074 & $.014^{*}$ & Total & 2.18 & 0.069 & $.014 *$ \\
\hline$C-0 m$ & 2.48 & 0.077 & $.014^{*}$ & $\mathrm{C}-0 \mathrm{~m}$ & 1.11 & 0.035 & .418 \\
\hline$C-5 m$ & 1.87 & 0.059 & .110 & $C-5 m$ & 2.55 & 0.072 & $.021 *$ \\
\hline $\mathrm{C}-10 \mathrm{~m}$ & 1.45 & 0.047 & .238 & $C-10 m$ & 1.32 & 0.045 & .364 \\
\hline $0 m-5 m$ & 1.30 & 0.044 & .238 & $0 m-5 m$ & 1.78 & 0.055 & .107 \\
\hline $0 m-10 m$ & 1.23 & 0.041 & .273 & $0 m-10 m$ & 1.08 & 0.038 & .418 \\
\hline $5 m-10 m$ & 1.19 & 0.038 & .273 & $5 m-10 m$ & 1.03 & 0.034 & .438 \\
\hline
\end{tabular}

(Fig. 3A-D, Table 2). Regarding total abundance, only the ' $0 \mathrm{~m}$ ' group had lower values than the control, and the ' $5 \mathrm{~m}$ ' group had higher values than the ' $0 \mathrm{~m}$ ' and the ' $10 \mathrm{~m}$ ' groups. Forest specialist spiders were fewer in the ' $0 \mathrm{~m}$ ' group than in the other groups, which, in turn, did not differ from each other. We detected no significant difference between the control and the other groups regarding open habitat species but we caught significantly more individuals in the ' $5 \mathrm{~m}$ ' group than in the ' $0 \mathrm{~m}$ ' and ' $10 \mathrm{~m}$ ' groups.

In the meadows, treatment affected only the abundance of forest specialist species, whereas the total abundance and the abundance of open habitat specialist and generalist species showed no significant treatment effect (Fig. 3E-H, Table 2). Both the ' $0 \mathrm{~m}$ ' and ' $5 \mathrm{~m}$ ' groups had fewer forest specialists than the control and the difference was also significant between the ' $0 \mathrm{~m}$ ' and the ' $10 \mathrm{~m}$ ' groups, with the latter being more abundant in forest specialist spiders.

\subsection{Carabid beetles}

We caught a total of 1148 carabid individuals of 57 species, which included 12 forest specialist, 23 open habitat specialist and 22 generalist species. There were 542 individuals in the forests (37 species) and 606 (50 species) in the meadows. Treatment had significant effect on the composition of carabid assemblages in both habitats (Table 1). The pairwise comparisons of the forest data indicated that the control differed from the ' $0 \mathrm{~m}$ ' group, while the other comparisons yielded nonsignificant results. The PCA scatterplot of forest carabids (Fig. 2C) also indicated a separation between the control and the ' $0 \mathrm{~m}$ ' group. There was no overlap between the ' $0 \mathrm{~m}$ ' and the ' $10 \mathrm{~m}$ ' groups either but the compositional difference was not confirmed statistically with the corresponding pairwise perMANOVA. In the meadows, we detected significant difference only between the control and the ' $5 \mathrm{~m}$ ' group, which was in line with the patterns of the PCA scatter plot (Fig. 2D), showing a separation between these groups and a considerable overlap between other group pairs.

Regarding carabids in the forests, all GLMMs were significant (Fig. 3I-L, Table 2). Total abundance was significantly lower in the ' 0 $\mathrm{m}$ ' group than in all other groups, and the ' $5 \mathrm{~m}$ ' group tended to have more individuals than the control but we detected only marginal significance. The other pairwise comparisons yielded nonsignificant results. Forest specialist carabids were less abundant in the ' $0 \mathrm{~m}$ ' group than in the other groups, whereas these latter groups did not significantly differ from each other. Open habitat specialists were more abundant in the control and the ' $5 \mathrm{~m}$ ' group than in the ' $0 \mathrm{~m}$ ' and ' $10 \mathrm{~m}$ ' groups. We detected no difference between the control and the ' $5 \mathrm{~m}$ ' group and between the ' $0 \mathrm{~m}$ ' and the ' $10 \mathrm{~m}$ ' groups. We caught more generalist species in every treated group than in the control and there were more carabids in the ' $5 \mathrm{~m}$ ' group than in the ' $0 \mathrm{~m}$ ' group.

In the meadows, treatment had no detectable effect on either the total abundance of carabids or the abundance of forest and open habitat specialist species. However, we detected a marginal significance for generalist species; thus, we did the pairwise comparisons. These indicated significantly more carabids in the ' $5 \mathrm{~m}$ ' group than in the control and the ' $10 \mathrm{~m}$ ' groups (Fig. $3 \mathrm{M}-\mathrm{P}$, Table 2).
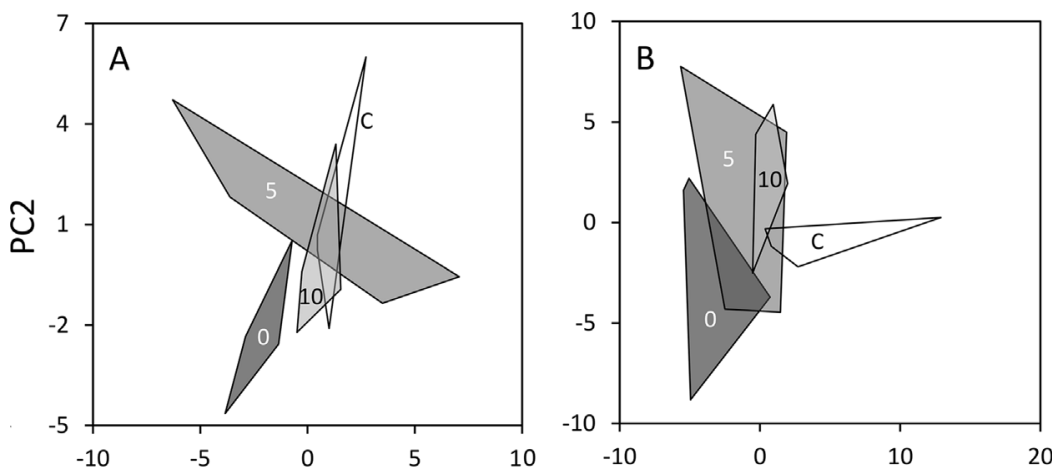

Fig. 2. Scatterplots of principal component analysis of spiders in the forests (A) and meadows (B) and carabids in the forests (C) and meadows (D). Vertices of the polygons represent forest edge sites (pooled data of four traps). C: unmowed control; 0: zero buffer; 5 : narrow ( $5 \mathrm{~m}$ ) buffer; 10 : wide $(10 \mathrm{~m})$ buffer. Variances covered by the first two axes: $2 \mathrm{~A}: 29.3$ and $24.4 \%$, 2B: 35.3 and $32.1 \%$, 2C: 37.9 and $14.1 \%$, 2D: 24.5 and $12.9 \%$.
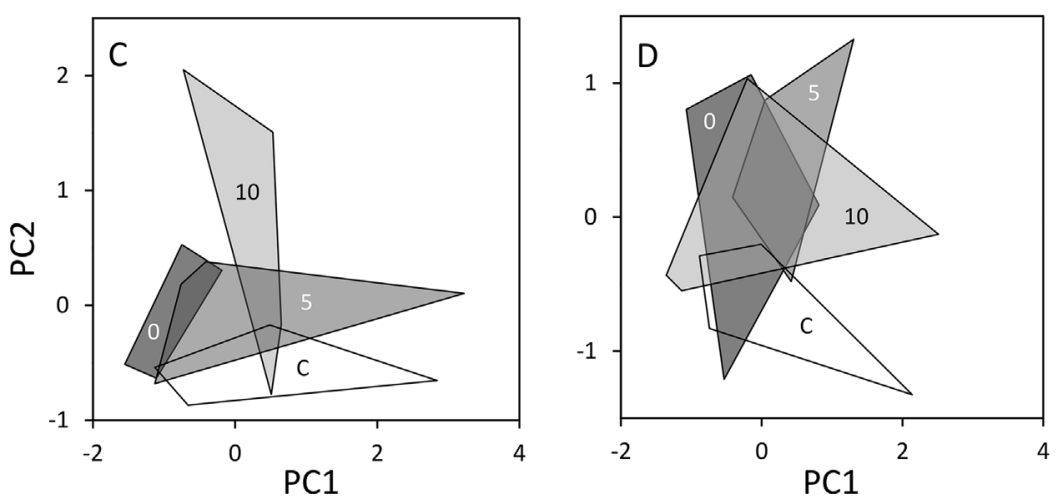
Total abundance
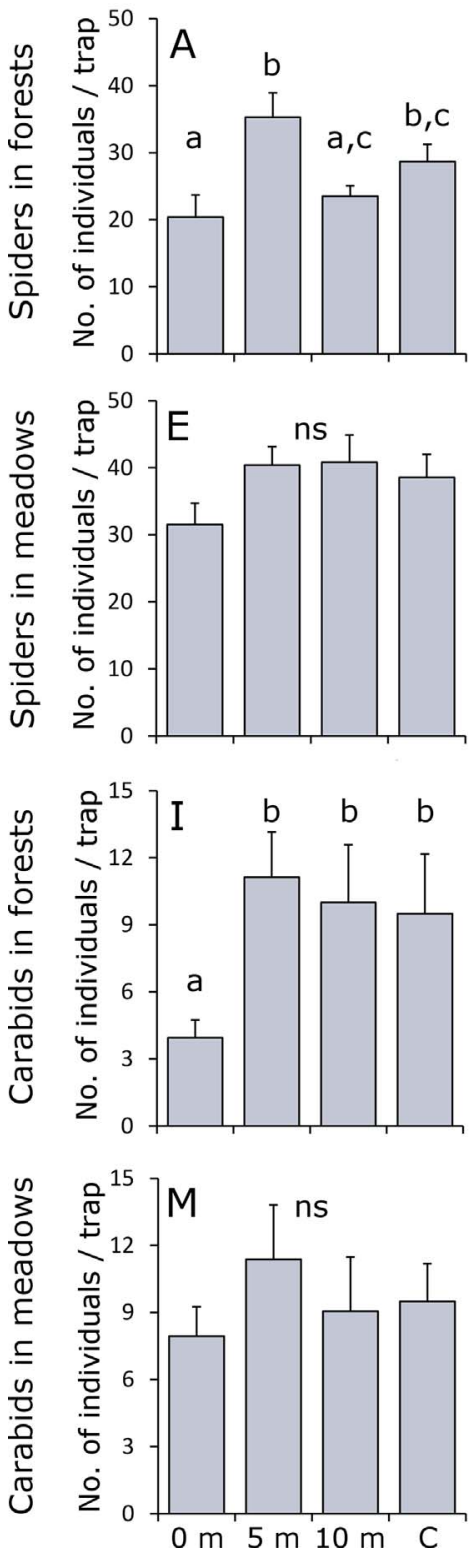

Forest species
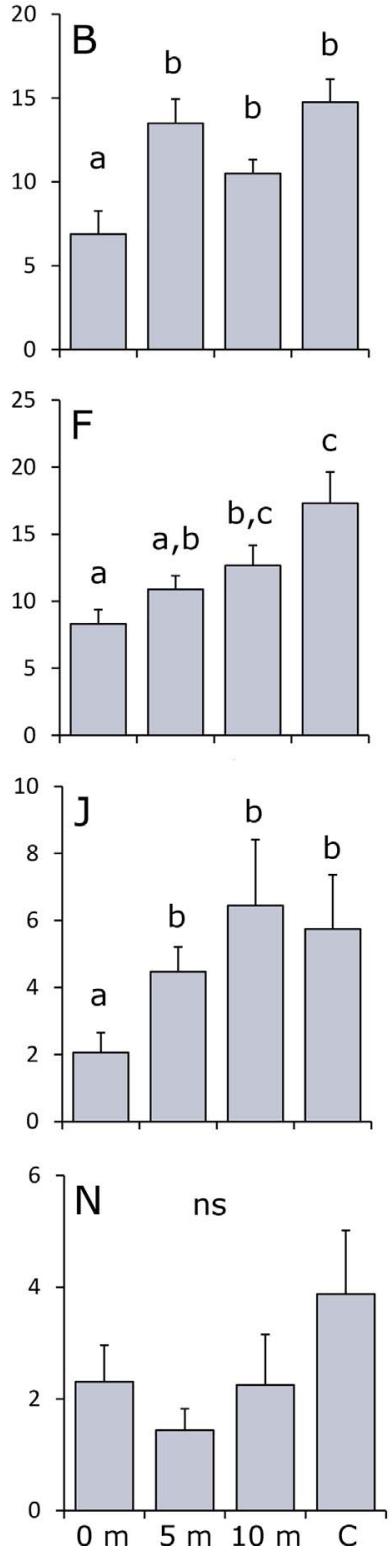

Open species
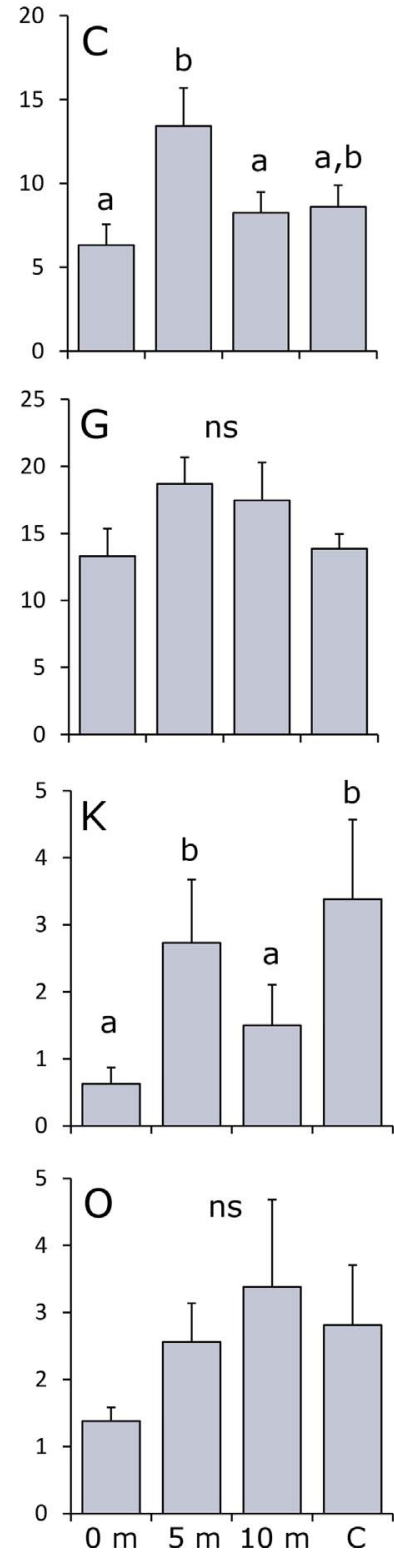

Generalist species
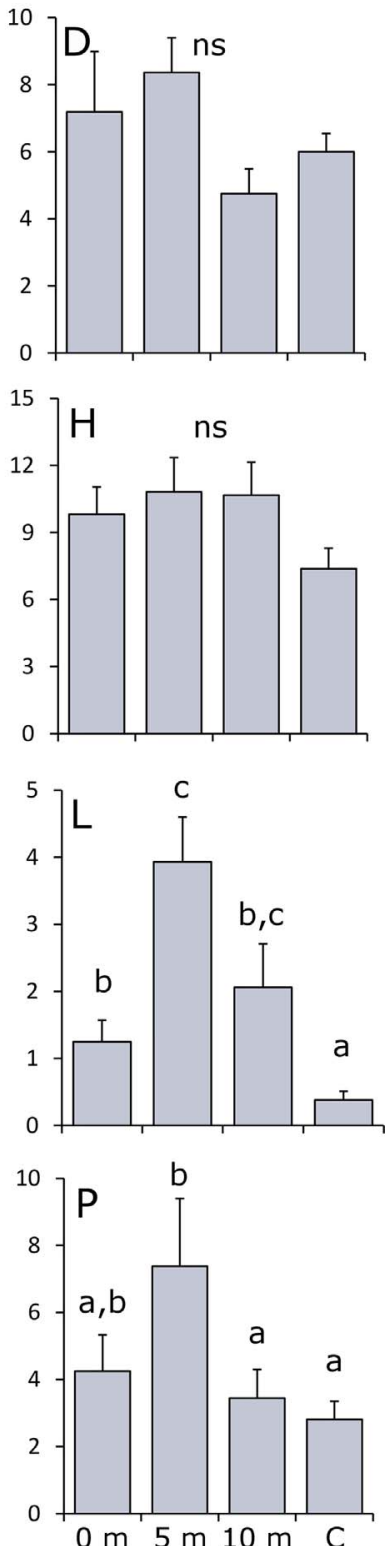

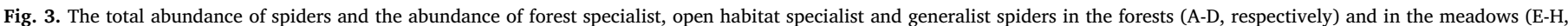

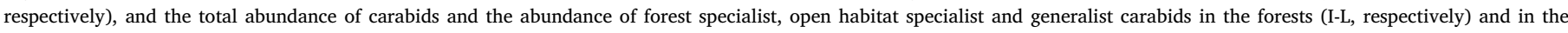

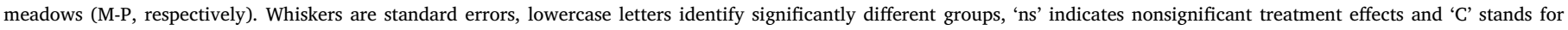
control.

\section{Discussion}

\subsection{Compositional patterns}

We found that mowing resulted in significant changes in the species composition of both habitats, indicating a strong cross-edge effect of mowing. It appears that leaving a narrow $(5 \mathrm{~m})$ buffer may offset the compositional perturbations in the forests, although a marginal compositional difference was still detectable for spiders. In the meadows, even the wide buffer was not enough to avoid all compositional changes for spiders.

Interestingly, some of our results suggest that the effect of the narrow buffer zone is not intermediate between the zero buffer $(0 \mathrm{~m})$ and the wide buffer, as (i) the composition of the narrow buffer group and the control differed in a case, where the zero buffer did not differ from the control (see carabids in the meadows) and (ii) in another case the control did not differ significantly from either the narrow or the wide buffers but the narrow and the wide buffers did differ from each other (see spiders in the forest). The effects of buffers are therefore likely to be more complex than anticipated. The models prepared for the total and trait-specific abundances did, however, shed light on the main trends.

\subsection{Abundance patterns in the meadows}

We found that treatment did not affect the total abundance of either arthropod taxon in the meadows but the abundance of forest specialist spiders decreased due to mowing. This decrease in abundance was less severe when a narrow buffer was applied and was no more detectable with the wide one as compared to the unmown control. This reaction of the forest specific species can be explained by their sensitivity to dry and warm microclimate (Magura et al., 2001; Noreika and Kotze, 


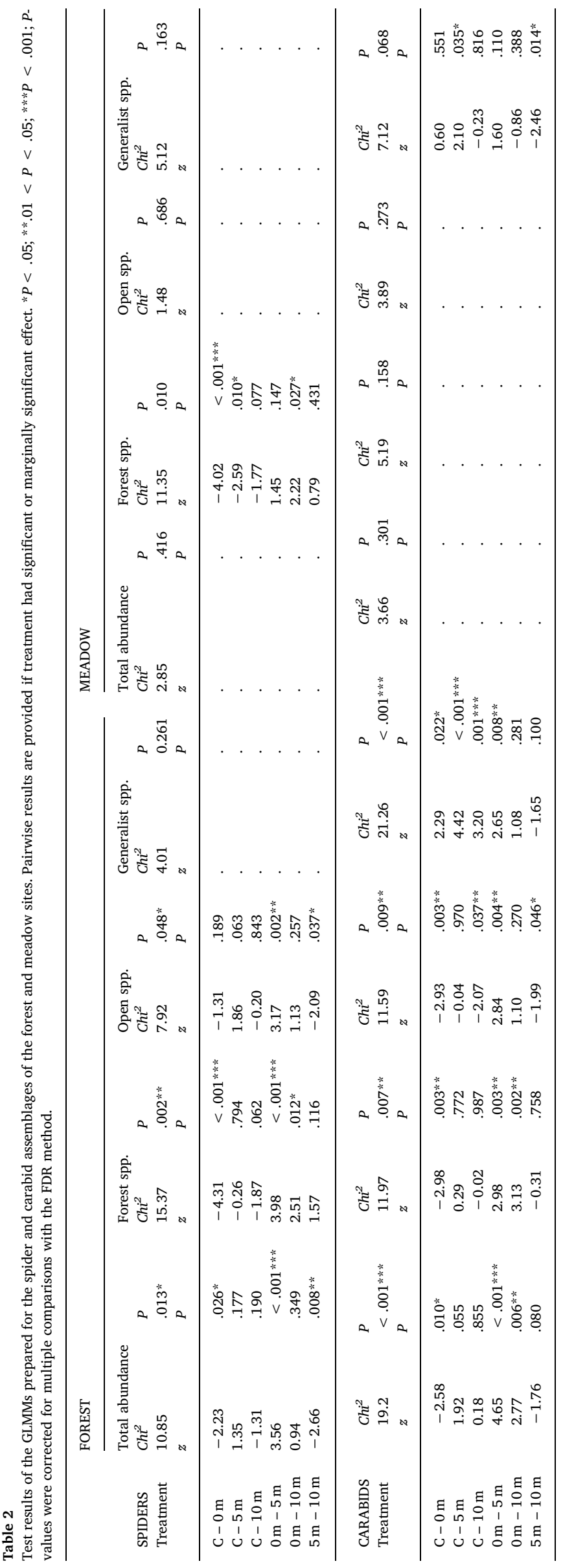

2012), which is typical of freshly mown meadows (Collinge and Palmer, 2002). Thus, the spillover of forest specialist spiders, which is apparent in the control sites, is suppressed by mowing, and a wide buffer is needed to fully offset this effect. Forest specialist carabids were less affected, with no significant differences among treatment groups; however, the lack of significance may have also been caused by the high variability of the data. Contrary to other studies (e.g. Lebeau et al., 2015), we found no evidence for the buffers being shelters for open habitat species after mowing, for either taxon. However, this may at least partly be explained by the fact that the surface of freshly mown meadows is warmer and devoid of appropriate shelter, which can lead to higher arthropod activity and catching rate (Honek, 1997), obscuring any sheltering effect of the buffer strips as well as the difference between zero buffer sites and controls.

We could not detect any mowing-induced change in generalist carabids either, but the narrow buffer proved to be an important refuge for them, corresponding to the "landscape-moderated concentration and dilution hypothesis" of Tscharntke et al. (2012). Such concentration was no more detectable when the buffer was wide enough. This finding can explain the non-transitional compositional features of the narrow buffer as indicated by the perMANOVAs.

\subsection{Abundance patterns in the forests}

Interestingly, the linear models revealed more significant changes in the forests than in the meadows, where the mowing occurred. Parallel to the reduction of the spillover of forest specialists toward grasslands, this species group withdrew from the peripheral zone of the forests as well. The narrow buffer was enough to offset this effect for both taxa. This finding adds a new facet to the well-known vulnerability of small forest patches or patches that have complex edge contours and hence high perimeter to area ratio (Madeira et al., 2016). If grasslands are mown around these forest patches without leaving buffers, the forest patches may lose their core area temporarily and become unsuitable to sustain permanent forest specialist assemblages in the long run. This can be prevented by using unmown buffers during mowing, potentially enabling the smallest forest patches, including solitary trees, to sustain their own species and contribute to the landscape scale diversity and ecological functionality, similar to extensively grazed wood-pastures (Gallé et al., 2017).

Compared to the control sites, we did not detect a higher influx of open habitat species into the forests after mowing if no buffer was left. Although open habitat specialists might be looking for suitable shelters after mowing, forest patches are not an option for them. In fact, we caught fewer open habitat specialist spiders and carabids in the forest traps of zero buffer sites than in control sites, which, together with the retraction of forest specialists, contributed to the decrease of the total abundance of both taxa. This finding contrasts with several other studies claiming that the abrupt decline of habitat quality can trigger spillover by driving arthropods from the affected habitat to neighbouring ones (Eyre et al., 2013; Opatovsky and Lubin, 2012; Rand et al., 2006). According to the edge permeability hypothesis (Stamps et al., 1987) and several case studies (Collinge and Palmer, 2002; Noreika and Kotze, 2012; Inclán et al., 2015), edges with high contrast represent stronger barriers for arthropod dispersal than softer edges, and the contrast was indeed higher between the meadows and the forests after mowing. However, when the contrast was softened by the narrow buffer, both open habitat spiders and carabids spilled into the peripheral zone of the forests. This effect was not detectable with the wide buffer, perhaps because the higher amount of suitable habitat did not necessitate further searches for alternative habitats. This facilitation of spillover was also reflected in the total spider abundances, as more spiders were present in forests when narrow buffers were applied than when wide ones. Generalist carabids showed a similar, albeit more pronounced spillover pattern toward forests. Despite the increased contrast, their spillover into forests increased after mowing, probably 
because forests are not as far from their optimum than for the open habitat specialists. The narrow buffer further increased the influx of generalist species and even the wide buffer had a positive effect on their spillover compared with the control. These findings are in line with other studies claiming that generalists are the main contributors of spillover across habitat edges (e.g. Schneider et al., 2013; Torma and Gallé, 2011).

The facilitative effect of narrow buffers on spillover into forests can be either beneficial or undesirable. It is beneficial when the species that temporarily find shelter in the peripheral zones of forests are of conservation importance and their long-term persistence is supported by this mechanism, as a novel, management-assisted landscape complementation. Leaving unmown strips or patches away from forest fragments may potentially have similar beneficial effects (Humbert et al., 2012b; Lebeau et al., 2015). Conversely, the increased spillover of spiders and carabids can interfere with trophic interactions in the forests, creating higher predatory pressure on forest-specific prey assemblages and increasing competition with forest-specific predators (Boetzl et al., 2016; Lacasella et al., 2015; Rand et al., 2006). As a result, leaving either zero buffer or a wide buffer may be a better option than leaving a narrow buffer if the net effect of the spillover from grasslands is considered negative for landscape level biodiversity and ecosystem functions.

\section{Conclusions}

Although the detected trends of carabids and spiders were not completely symmetrical regarding either composition or abundance, none of the statistically confirmed differences were contrasting. In fact, the results of spiders and carabids supplemented each other to receive a coherent view on the effects of the treatments.

We conclude that unmown buffers along forest edges can, depending on their width, reduce or completely offset the effects of mowing on the composition of arthropod assemblages of forests. However, even wide buffers cannot fully preserve species composition in the peripheral zones of meadows. Regarding abundance change, spillover from forests is reduced by mowing but this can fully be reversed by applying wide buffers. Changes inside forests are more complex. Forest specialists withdraw from the peripheral zones but open habitat specialists do not necessarily enter the forests in higher numbers. The application of narrow buffers can facilitate the influx of open habitat specialists and generalists but this effect disappears when using wide buffers. On the basis of these findings, spillover should be considered when planning mowing in grassland-forest mosaics. We recommend using wide buffers but since this can also lead to shrub or tree encroachment, the application of wide buffers should be alternated with zero buffers both in space and time. Narrow unmown buffers along the forest edges should mostly be avoided as they can facilitate unwanted spillover. The actual width of effective buffers may vary according to different climatic regimes, different forest and grassland types, and management intensity; thus, choosing the right width may require local optimization. If, for instance, the grassland is more intensively used than in our case, generalist species may have a higher proportion and could pose a higher threat to the forest assemblages after mowing due to their higher mobility across edges. In such cases, buffers wider than $10 \mathrm{~m}$ may be necessary.

Future research should also test the application of buffers in preventing undesirable changes of spillover in forest-cropland mosaics. Although unharvested crop strips do not seem a feasible option, extensively used, permanent grassland buffers, as also recommended by Madeira et al., 2016, may be more appropriate for the purpose. Our results, however, indicate that simply deciding for the use of buffers is not enough. It may be necessary to test multiple buffer widths, because a too narrow buffer may not only have lower efficiency but may have an opposite effect compared to the intended one.

\section{Acknowledgements}

The authors thank to Csaba Biró for help in the logistics in the field and all site managers for their careful adherence to the study design. We are also grateful to Nikolett Gallé-Szpisjak for identifying spiders. The contribution of CT and PT was supported by the Lendület Program of the Hungarian Academy of Sciences. The support of the National Research, Development and Innovation Office of Hungary is greatly acknowledged (PT: NKFIH K 119 225, RG: NKFIH FK 124 579, ZB: NKFIH K 124 796).

\section{References}

Báldi, A., Batáry, P., Kleijn, D., 2013. Effects of grazing and biogeographic regions on grassland biodiversity in Hungary - analysing assemblages of 1200 species. Agric. Ecosyst. Environ. 166, 28-34.

Bates, D., Maechler, M., Bolker, B., Walker, S., 2015. Fitting linear mixed-effects models using lme4. J. Stat. Softw. 67, 1-48.

Blitzer, E.J., Dormann, C.F., Holzschuh, A., Klein, A.M., Rand, T.A., Tscharntke, T., 2012 Spillover of functionally important organisms between managed and natural habitats. Agric. Ecosyst. Environ. 146, 34-43.

Boetzl, F.A., Schneider, G., Krauss, J., 2016. Asymmetric carabids beetle spillover between calcareous grasslands and coniferous forests. J. Insect Conserv. 20, 49-57.

Buchar, J., Ruzicka, V., Merrett, P., 2002. Catalogue of Spiders of the Czech Republic. Peres, Praha.

Buri, P., Arlettaz, R., Humbert, J.-Y., 2013. Delaying mowing and leaving uncut refuges boosts orthopterans in extensively managed meadows: evidence drawn from fieldscale experimentation. Agric. Ecosyst. Environ. 181, 22-30.

Cizek, O., Zamecnik, J., Tropek, R., Kocarek, P., Konvicka, M., 2012. Diversification of mowing regime increases arthropods diversity in species-poor cultural hay meadows. J. Insect Conserv. 16, 215-226.

Collinge, S.K., Palmer, T.M., 2002. The influences of patch shape and boundary contrast on insect response to fragmentation in California grasslands. Landsc. Ecol. 17, 647-656.

Cook, W.C., Lane, K.T., Foster, B.L., Holt, R.D., 2002. Island theory, matrix effects and species richness patterns in habitat fragments. Ecol. Lett. 5, 619-623.

Dengler, J., Janišová, M., Török, P., Wellstein, C., 2014. Biodiversity of Palaearctic grasslands: a synthesis. Agric. Ecosyst. Environ. 182, 1-14.

Duflot, R., Ernoult, A., Burel, F., Aviron, S., 2016. Landscape level processes driving carabid crop assemblage in dynamic farmlands. Popul. Ecol. 58, 265-275.

Dunning, J.B., Danielson, B.J., Pulliam, H.R., 1992. Ecological processes that affect populations in complex landscapes. Oikos 65, 169-175.

Eyre, M.D., Luff, M.L., Leifert, C., 2013. Crop, field boundary, productivity and disturbance influences on ground beetles (Coleoptera: carabidae) in the agroecosystem. Agric. Ecosyst. Environ. 165, 60-67.

Fahrig, L., Baudry, J., Brotons, L., Burel, F.G., Crist, T.O., Fuller, R.J., Sirami, C., Siriwardena, G.M., Martin, J.-L., 2011. Functional landscape heterogeneity and animal biodiversity in agricultural landscapes. Ecol. Lett. 14, 101-112.

Freude, H., Harde, K.W., Müller-Motzfeld, G., Lohse, G.A., Klausnitzer, B., 2004. Die Käfer Mitteleuropas, Adephaga 1. Carabidae Laufkäfer. Spektrum Akademischer Verlag, Munich.

Gallé, R., Urák, I., Nikolett, G.-S., Hartel, T., 2017. Sparse trees and shrubs confers a high biodiversity to pastures: case study on spiders from Transylvania. PLoS One 12, e0183465.

Holt, R.D., Hochberg, M.E., 2001. Indirect interactions, community models and biological control: a theoretical perspective. In: Wajuberg, E., Scott, J.K., Quimby, P.C. (Eds.), Evaluating Indirect Ecological Effects of Biological Control. CAB International, New York, pp. 13-37.

Honek, A., 1997. The effect of temperature on the activity of Carabidae (Coleoptera) in a fallow field. Eur. J. Entomol. 94, 97-104.

Humbert, J.-Y., Pellet, J., Buri, P., Arlettaz, R., 2012a. Does delaying the first mowing date benefit biodiversity in meadowland? Environ. Evid. 1, 9.

Humbert, J.-Y., Ghazoul, J., Richner, N., Walter, T., 2012b. Uncut grass refuges mitigate the impact of mechanical meadow harvesting on orthopterans. Biol. Conserv. 152, 96-101.

Hurka, K., 1996. Carabidae of the Czech and Slovak Republics. Kabourek, Zlin.

Inclán, D.J., Cerretti, P., Marini, L., 2015. Landscape composition affects parasitoid spillover. Agric. Ecosyst. Environ. 208, 48-54.

Lacasella, F., Gratton, C., De Felici, S., Isaia, M., Zapparoli, M., Marta, S., Sbordoni, V., 2015. Asymmetrical responses of forest and "beyond edge" arthropod communities across a forest-grassland ecotone. Biodivers. Conserv. 24, 447-465.

Lambert, M., Harris, S.J., Brown, V.K., 2007. The importance of sward architectural complexity in structuring predatory and phytophagous invertebrate assemblages. Ecol. Entomol. 32, 302-311.

Lebeau, J.L., Wesselingh, R.A., van Dyck, H., 2015. Butterfly density and behaviour in uncut hay meadow strips: behavioural ecological consequences of an agri-environmental scheme. PLoS One 10, e0134945.

Lucey, J.M., Hill, J.K., 2012. Spillover of insects from rain forest into adjacent oil palm plantations. Biotropica 44, 368-377.

Macfadyen, S., Muller, W., 2013. Edges in agricultural landscapes: species interactions and movement of natural enemies. PLoS One 8, e59659.

Madeira, F., Tscharntke, T., Elek, Z., Kormann, U.G., Pons, X., Rösch, V., Samu, F., 
Scherber, C., Batáry, P., 2016. Spillover of arthropods from cropland to protected calcareous grassland - the neighbouring habitat matters. Agric. Ecosyst. Environ. 235, 127-133.

Magura, T., Ködöböcz, V., Tóthmérész, B., 2001. Effects of habitat fragmentation on carabids in forest patches. J. Biogeogr. 28, 129-138.

Marty, J.T., 2005. Effects of cattle grazing on diversity in ephemera wetlands. Conserv. Biol. 19, 1626-1632.

Molnár, Z., Horváth, F., Litkey, Z., Walkovszky, A., 1997. A Duna-Tisza közi kőrises égerlápok története és mai állapota. Természetvédelmi Közlemények 5 (-6), 55-77 [in Hungarian].

Murcia, C., 1995. Edge effects in fragmented forests: implications for conservation. Trends Ecol. Evol. 10, 58-62.

Noreika, N., Kotze, D.J., 2012. Forest edge contrasts have predictable effect on the spatial distribution of carabid beetles in urban forests. J. Insect Conserv. 16, 867-881.

Oksanen, J., Blanchet, F.G., Kindt, R., Legendre, P., Minchin, P.R., O'Hara, R.B., Simpson, G.L., Solymos, P., Stevens, M.H.H., Wagner, H., 2016. Vegan: Community Ecology Package R Package Version 2. pp. 3-5.

Opatovsky, I., Lubin, L., 2012. Coping with abrupt decline in habitat quality: effects of harvest on spider abundance and movement. Acta Oecol. 41, 14-19.

Pearce, J.L., Venier, L.A., 2006. The use of ground beetles (Coleoptera: carabidae) and spiders (Araneae) as bioindicators of sustainable forest management: a review. Ecol. Indic. 6, 780-793.

Pryke, J.S., Samways, M.J., 2012. Ecological networks act as extensions of protected areas for arthropod biodiversity conservation. J. Appl. Ecol. 49, 591-600.

Core Team, R., 2014. R Core Team: A Language and Environment for Statistical Computing. R Foundation for Statistical Computing, Vienna.

Rand, T.A., Louda, S.A., 2006. Spillover of agriculturally subsidized predators as a potential threat to native insect herbivores in fragmented landscapes. Conserv. Biol. 20, 1720-1729.

Rand, T.A., Tylianakis, J.M., Tscharntke, T., 2006. Spillover edge effects: the dispersal of agriculturally subsidized insect natural enemies into adjacent natural habitats. Ecol. Lett. 9, 603-614.

Ries, L., Sisk, T.D., 2004. A predictive model of edge effects. Ecology 85, 2917-2926.

Schneider, G., Krauss, J., Steffan-Dewenter, I., 2013. Predation rates on semi-natural grasslands depend on adjacent habitat type. Basic Appl. Ecol. 14, 614-621.
Stamps, J.A., Buechner, M., Krishnan, V.V., 1987. The effects of edge permeability and habitat geometry on emigration from patches of habitat. Am. Nat. 129, 533-552. Sutherland, W.J., 2002. Openness in management. Nature 418, 834-835.

Tälle, M., Deák, B., Poschlod, P., Valkó, O., Westerberg, L., Milberg, P., 2016. Grazing vs. mowing: a meta-analysis of biodiversity benefits for grassland management. Agric. Ecosyst. Environ. 15, 200-212.

Tölgyesi, C., Bátori, Z., Erdős, L., Gallé, R., Körmöczi, L., 2015. Plant diversity patterns of a Hungarian steppe-wetland mosaic in relation to grazing regime and land use history. Tuexenia 35, 399-416.

Tölgyesi, C., Erdős, L., Körmöczi, L., Bátori, Z., 2016. Hydrologic fluctuations trigger structural changes in wetland-dry grassland ecotones but have no effect on ecotone position. Commun. Ecol. 17, 188-197.

Török, P., Valkó, O., Deák, B., Kelemen, A., Tóth, E., Tóthmérész, B., 2016. Managing fo species composition or diversity? Pastoral and free grazing systems in alkali steppes. Agric. Ecosyst. Environ. 234, 23-30.

Thorbek, P., Bilde, T., 2004. Reduced numbers of generalist arthropod predators after crop management. J. Appl. Ecol. 41, 526-538.

Torma, A., Gallé, R., 2011. Fine scale pattern of true bug assemblages (Heteroptera) across two natural edges. Acta Zool. Hung. 57, 367-383.

Tscharntke, T., Tylianakis, J.M., Rand, T.A., Didham, R.K., Fahrig, L., Batáry, P., Bengtsson, J., Clough, Y., Crist, T.O., Dormann, C.F., Ewers, R.M., Fründ, J., Holt, R.D., Holzschuh, A., Klein, A.M., Kleijn, D., Kremen, C., Landis, D.A., Laurance, W., Lindenmayer, D., Scherber, C., Sodhi, N., Steffan-Dewenter, I., Thies, C., van der Putten, W.H., Westphal, C., 2012. Landscape moderation of biodiversity patterns and processes - eight hypotheses. Biol. Rev. 87, 661-685.

Vadász, C., Lóránt, M., 2015. Key mortality causes of the Great Bustard (Otis tarda) in central Hungary: an analysis of known fatalities. Ornis Hung. 22, 32-41.

Vera, F.W.M., 2002. Grazing Ecology and Forest History. CABI, Oxon.

Woodcock, B.A., Potts, S.G., Westbury, D.B., Ramsay, A.J., Zurbrügg, K., Frank, T., 2006 Factors influencing bug diversity (Insecta: Heteroptera) in semi-natural habitats. Biodivers. Conserv. 15, 275-294.

van Klink, R., Boch, S., Buri, P., Rieder, N., Humbert, J.-Y., Arlettaz, R., 2017. No detrimental effects of delayed mowing or uncut grass refuges on plant and bryophyte community structure and phytomass production in low-intensity hay meadows. Basic Appl. Ecol. 20, 1-9. 